\title{
Central African forests, carbon and climate change
}

\author{
Chris Justice $^{1, *}$, David Wilkie ${ }^{2, * *}$, Quanfa Zhang ${ }^{1}$, Jake Brunner ${ }^{3}$, Cinde Donoghue $^{1, * * *}$ \\ ${ }^{1}$ Global Environmental Change Program, Department of Environmental Sciences, University of Virginia, Charlottesville, \\ Virginia 22903, USA \\ ${ }^{2}$ Associates in Forest Research and Development, Waltham, Massachusetts 02154, USA \\ ${ }^{3}$ World Resources Institute, Washington, DC 20002, USA
}

\begin{abstract}
The tropical forests of the world are receiving considerable attention in terms of their role in climate change. Not only does tropical land use change provide an important term in balancing the global carbon budget, but tropical forests also present opportunities for carbon trading in the emerging carbon markets. The Congo Basin contains the second largest area of contiguous rainforest in the world, yet for various reasons has received relatively little attention in terms of these climate change issues. This paper provides an assessment of the current state of the forests of Central Africa, their carbon stock, recent rates of deforestation and a simple predictive model of forest change over the next $60 \mathrm{yr}$. The roles of agriculture and logging which are driving deforestation are discussed. The future of the forests, whether for commercial use, carbon trading or biodiversity is inextricably linked to how these valuable resources are managed. Suggestions are made for potential carbon trading projects, forest management strategies and a climate change research agenda for the region. Effective forest monitoring and management are seen as essential components for the economic development of this region.
\end{abstract}

KEY WORDS: The Congo Basin $\cdot$ Climate change $\cdot$ Carbon $\cdot$ Forest management and policy

Resale or republication not permitted without written consent of the publisher

\section{INTRODUCTION}

Tropical forests have featured prominently in discussions of climate change. The focus has been largely on deforestation and the greenhouse gases released to the atmosphere as large areas of tropical forest are cleared and mostly converted to pasture or agriculture. The deforestation term is recognized as being important to balance the global carbon budget (Houghton 1995). Recently, attention is reaching beyond just land clearing to provide a more complete picture of the tropical forest carbon budget by considering issues such as sequestration from pasture abandonment and forest regrowth, emissions from wild fires, carbon loss from

*E-mail: justice@virginia.edu

Present addresses:

${ }^{* *}$ Wildlife Conservation Society, Bronx, New York 10460, USA, and Boston College, Chestnut Hill, Massachusetts 02467, USA

***Washington State Department of Ecology, Olympia, Washington 98504-8711, USA logging practices and biomass collapse associated with forest fragmentation (Laurance et al. 1997, Kimes et al. 1998, Nepstad et al. 1999, Houghton et al. 2000).

Over the past decade, questions of emissions and mitigation have dominated the climate change debate as the signature countries to the UN Framework Convention on Climate Change (UNFCCC) are required to report their anthropogenic emissions of greenhouse gases (Okoth-Ogenda et al. 1985, Braatz et al. 1995, Callendar 1995). The Kyoto Protocol has evolved and the Clean Development Mechanism (CDM, Article 12) and Joint Implementation (JI, Article 4) now present new opportunities for developing countries to become involved in carbon trading. These mechanisms allow Annex 1 countries, which are largely industrialized countries, to meet their commitments by undertaking projects with non-Annex 1 countries, which are largely developing countries (Ojwang \& Karani 1995). In developing countries there is considerable interest in the potential revenue from carbon trading and concern about the impacts of climate change on development, human health and national economies. 
Greenhouse gas emissions are widely viewed as an issue for the industrialized countries of the world (Kuik \& Gupta 1996, Justice et al. in press). Estimated carbon emissions for fossil fuel and land use from the African continent in 1990 were 0.19 and 0.4 Pg respectively, which together account for $7.7 \%$ of global carbon dioxide emissions (Houghton 1995).

As the topic of climate change becomes more established, countries are positioning themselves to respond to the issues at political and policy levels (Maya \& Churie 1996). The countries of Central Africa ${ }^{1}$ with the exception of Equatorial Guinea are signatories to the Climate Convention, yet Central Africa has received considerably less attention than other tropical forest regions of the World and has not featured strongly in the climate change debate. However the large expanses of humid tropical forests hold much of Africa's carbon, and the general level of vulnerability of the peoples and economies of the region make Central Africa an important region for consideration in terms of climate change impacts.

The US Congress has directed the US Agency for International Development (USAID) to develop climate change as part of its development portfolio and in response USAID has identified South Africa and the Congo Basin as the 2 focus regions for their climate change activities in Africa (USAID 1998). The climate change activities for the Congo Basin are being undertaken as part of the Central Africa Regional Project for the Environment (CARPE; http://carpe.umd.edu), which has a primary focus on developing conditions for reducing deforestation and preserving biodiversity. It is clear that whether one is concerned with quantifying or mitigating land use emissions, trading carbon or understanding the potential impacts of climate change, that there is a need for both effective forest management and monitoring. This paper presents a discussion of a number of issues associated with aspects of climate change and carbon, some preliminary findings from the CARPE program and an outlined agenda for climate change research in Central Africa.

\subsection{An historical perspective on the Congo Basin forests}

The majority of the area presently under forest within the Congo Basin is of relatively recent origin (Maley 1996). During the last global ice age, rainfall declined throughout the region and forests were restricted to remnant patches that constituted refuges

\footnotetext{
${ }^{1}$ In this paper Central Africa is composed of Cameroon, the Central African Republic (CAR), Congo, Equatorial Guinea, Gabon and the Democratic Republic of Congo (DRC)
}

for obligate forest species ( 20000-15000 BP). Only after the ice began to recede, did rainfall increase in the Basin and forest once again invade the savannas and re-dominate the landscape (8000 BP). Prior to and since this time, human foragers have hunted forest wildlife, gathered non-timber forest products, and occasionally felled unscalable trees to gather honey.

Farmers first began cultivating fields within the forest approximately $10000 \mathrm{yr} \mathrm{BP}$, but until the advent of iron tools (2000-700 BP) farmers had limited capacity to clear the forest for agriculture. Moreover, few crops indigenous to Africa are tolerant of rain forest conditions (e.g., oil palm Elais guineansis, white guinea yam Dioscorea rotundata and rice Oryza glaberrima). Thus, forest farming was relatively marginal as a subsistence practice, at least initially. It was not until plantains and bananas (Musa spp.) were introduced from Asia ( 1000-2000 BP) that farming became truly viable in the Congo Basin (Bahuchet 1990). In less than 1000 yr plantain cultivation had spread from the Red Sea to the coast of what is now Ghana, to be carried to the new world by 15th century Portuguese sailors (McMaster 1962). By this time, agriculture had received a further boost with the introduction of numerous crops from the Americas-maize, beans, peanuts, peppers, okra, cassava, avocado, papaya, squash, etc., plus cocoyams Colocasia esculenta, water yams Dioscorea alata, mango, coconut, citrus, from Asia, and breadfruit from Oceania. With iron tools and a suite of new forest tolerant crops, the viability of forest farming, and consequently the scale of farmers' occupation of and impact on the forest was able to increase significantly.

The ubiquity of carbonized oil palm kernels and iron furnaces throughout the Congo Basin are evidence of the long-term occupation of the forest by farmers (White \& Oates 1999). Moreover, archaeological evidence from several recent papers (White et al. 1998, White \& Oates 1999, Oslisly 2001) coupled with the age of trees that are currently being selectively but intensively exploited for timber suggests that the 'mahogany' (Entandrophragma, Khaya, Guarea spp.) forests of southwestern Nigeria, southeastern Cameroon, southwestern Central African Republic, and northern Congo, can be traced back to a period about 700-800 yr ago, when the relatively dense population of iron-age, oil-palm farmers moved away or died out from the area, leaving extensive areas of secondary forest and farmland to regenerate. The population of farmers in Gabon also appears to have peaked between 2500 and 1400 yr BP, based on the abundance of pottery, charred oil-palm fragments, and iron furnaces (Oslisly 1995), and to have crashed by 600 yr BP.

When humans disappeared, large areas of savanna and farmlands kept open by fires set by farmers were invaded by fast growing, light demanding, early suc- 
cessional species such as Aucoumea klaineana, which is now the dominant tree over $60 \%$ of Gabon. Though Aucoumea (Okoumé) constitutes over $65 \%$ of all logs harvested by Gabon's timber industry (De Dianous 1998), it does not regenerate under the canopy, present selective logging practices do not open sufficiently large light gaps to promote seedling survival, and young Okoumé are presently restricted to the edges of major logging roads, the trans-Gabonese railroad, around farmers villages, and in savannas protected by fire (White 2000). The fact that one of the most studied 'climax forest' trees in tropical Africa turns out to be a fallow field and savanna colonizer speaks to the limits of our knowledge of Congo Basin forest dynamics, and the important role that human land-use has and continues to play in shaping the structure and composition of the forest in the region.

Until very recently, forest resource exploitation within the Congo Basin was primarily at the household scale, which in aggregate terms has, at times, had a profound influence over forest species composition, distribution and abundance. By the 1890s, European merchants were using the rivers to transport ivory, skins and rubber to the coast and then Europe. It was not until the 1930s-40s that road construction initiated by the colonial governments began to enable access to tracks of forests isolated from navigable rivers. During this period the majority of human settlements that were dispersed along rivers throughout the forest were forcibly relocated alongside the roads, which were often constructed with forced labor. This mass resettlement process had, and continues to have, a profound impact on the spatial pattern of forest resource use.

As a consequence of infrastructure development and the post World War II economic boom, the $30 \mathrm{yr}$ between the 1930s and the 1960s was probably the most significant period of agricultural expansion and associated deforestation in the region in the 20th Century, as old-growth forest was cleared and converted to coffee, oil-palm, rubber, and banana plantations. Since that time, and with independence from France and Belgium, investment in rural infrastructure and in agricultural development has declined, as has the importance of industrial-scale agriculture in Congo Basin countries, excluding Cameroon. Discovery of oil in Congo, Gabon and most recently Equatorial Guinea has further shifted government interest away from agriculture. Timber remains, however, an important component of most national economies.

\subsection{A current perspective on the Congo Basin forests}

The Democratic Republic of Congo (DRC) is embroiled in a civil war that has seen the intervention of Uganda, Rwanda, Zimbabwe, Angola and Namibia both to stabilize border zones and to profit from the nation's mineral and timber wealth. The civil war in the DRC, though quiescent at present, still smolders, as warlords continue to struggle for exclusive access to massive oil revenues. The airport and hotels of Bangui, the capital of the Central Africa Republic, remain pockmarked with $50 \mathrm{~mm}$ cannon shells, after the end to a military struggle for power. Gabon, Cameroon and Equatorial Guinea are all comparatively tranquil, though like the rest of the region all have suffered economically with a $50 \%$ devaluation of the Central African Franc in 1992 and continued global fluctuations in oil and commodity prices. Though bilateral and multilateral donors continue to provide assistance to the region ( $\$ 450$ million $\mathrm{yr}^{-1}$ from 1993-1995; WRI 1998), civil strife and a perceived flagrant disregard for rule-of-law have constituted a massive disincentive to private-sector investments in the region that were a mere $\$ 60$ million $\mathrm{yr}^{-1}$ from 1993-1995, of which $89 \%$ went to Cameroon and Gabon (WRI 1998). Cameroon was recently cited as the most corrupt nation in the world by Transparency International (www.transparency. org/documents/cpi/).

Minerals (oil, copper, gold, diamonds, etc.) and timber remain the mainstays of the economies of the region. Transportation infrastructures are collapsing because of insufficient investment in maintenance; as a consequence, export agriculture is moribund, and domestic demand is insufficient to fuel agricultural growth and the associated local economic development. Tourism, which has augmented the economies of eastern and southern Africa, is unlikely to generate significant revenues given the insecurity in the region, the geographic isolation of parks and reserves, the paucity of reliably observable animals and the absence of a customer-service mentality (Wilkie \& Carpenter 1999). Lastly, lack of investment in education and in health care has left most central African nations at the bottom of global literacy and life expectancy rankings. All of these factors promote, understandably, a 'need to eat today' mentality amongst the typically poor citizens of the region and a focus on economic development by policy makers. This in turn militates against any discussion of forest conservation that does not result in some economic benefit to local communities and national treasuries, and places concerns about climate change and $\mathrm{CO}_{2}$ emissions very low on the priority list. Only if markets for carbon mature and the economic benefits from sequestering carbon, and retaining woody biomass on the land are tangible, will national policy makers be likely to pay much more than a passing interest in climate change. 


\section{STATUS OF THE CONGO BASIN FORESTS}

Central Africa contains the second largest contiguous area of tropical moist forest in the world, which constitutes about $15 \%$ of the world's remaining tropical moist forest (UNESCO 1978), encompassing the entire countries of Gabon and Equatorial Guinea, much of Congo, Cameroon, and the DRC, and the southwestern corner of the Central African Republic (Fig. 1). When wooded savannas are included, the forests of the Congo Basin cover approximately 2.8 million $\mathrm{km}^{2}$, an area about $1 / 3$ the size of the USA.

\subsection{Forest areal extent}

An up-to-date spatially explicit map of forest areal extent is considered necessary for a number of reasons, including large-area forest management and to quantify the extent of forest fragmentation. The areal extent of different vegetation types is also needed for a regional assessment of carbon stocks. Changes in areal extent through deforestation, degradation, regrowth and reforestation influences the carbon stock in any given area.

Estimation of the areal extent of tropical forests in central Africa has been hindered by forest inaccessibility, large forest extent, and limited available resources for national forest inventories (Wilkie 1994). Estimates of forest extent for Central Africa have been made by UN/FAO using questionnaires, national forest statis-

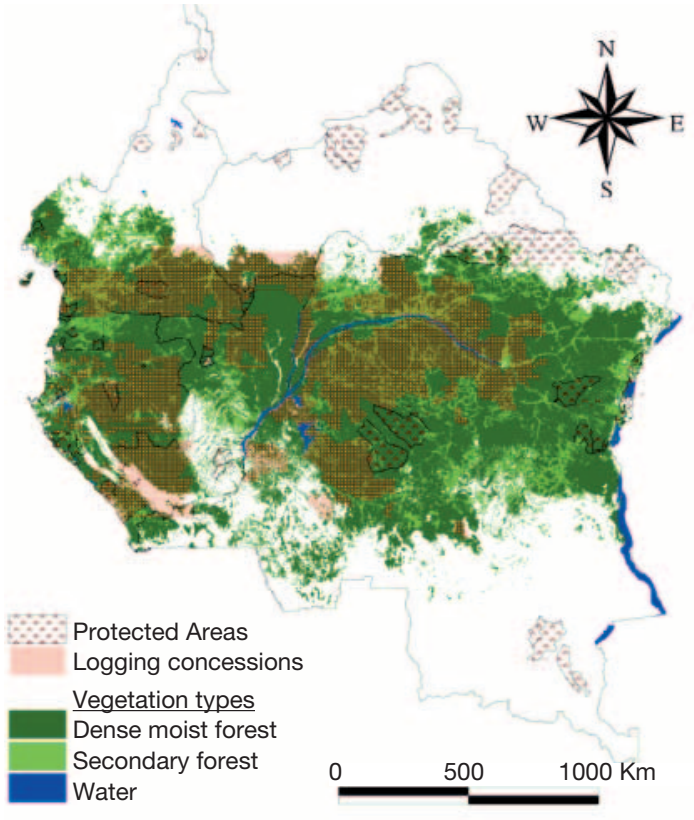

Fig. 1. Map of current forest extent, logging concessions and protected areas. Sources: forest extent, Mayaux et al. (1997); protected areas, Sayer et al. (1992); logging concessions, WRI's Global Forest Watch program tics, existing maps, and sample satellite imagery (FAO/ UNEP 1981, FAO 1993). The accuracy of these various data sources has been questioned and errors are difficult to quantify (Rodriquez Murillo 1997). In addition, variations of inventory and mapping methods among countries result in data inconsistencies (FAO 1993).

Increasingly, efforts are being made to estimate the areal extent of these forests through interpretation of remotely sensed images and maps (Justice et al. 1993, Laporte et al. 1995, Mayaux et al. 1997). Satellite remote sensing provides a means to quantify regional forest cover and enables mapping of vegetation in terms of cover type or density, e.g., closed forest, \% tree cover (Laporte et al. 1995). Remotely sensed data interpretation has the potential to bring up-to-date and spatially explicit information into the decision process; yet these estimates vary due to differences in methods and inconsistencies in classification types from study to study (Justice et al. 1993, Townshend et al. 1994, Mayaux et al. 1998). In addition, cloud cover, misinterpretation of land cover changes, and spectral overlap between classes cause errors when interpreting data with different spatial resolutions (Justice et al. 1993). Although there is very good agreement on the areal estimates at the global scale, differences of up to $15 \%$ at the country level and over $100 \%$ at the state level within a country exist (Mayaux et al. 1998). Currently the best estimate of moist forest extent in Central Africa is provided by the TREES project with an estimate of 1.8 million $\mathrm{km}^{2}$ (Mayaux et al. 1998).

\subsection{Forest rates of change}

The most widely cited deforestation estimate for the Congo Basin is from the UN FAO Tropical Resource Assessment 1990 report (FAO 1993). The estimate was corroborated using a sampling approach and Landsat satellite imagery. According to FAO, approximately $0.5 \%$ of the Congo Basin's dense forests are cleared each year. Compared to annual estimates of 1, 0.7 and $1.3 \%$ in West Africa, tropical South America and insular south Asia respectively. The rate of deforestation in the Congo Basin is relatively low at present, with the estimated deforestation in the Basin accounting for $5 \%$ of the annual total deforested area across the tropics.

Recognizing the need for synoptic mapping and monitoring, the NASA Landsat Pathfinder was initiated to map deforestation activities in closed tropical forests worldwide using Landsat Multispectral Scanner and Thematic Mapper (TM) imagery from the 1970s to the 1990s (Skole \& Tucker 1993, Skole et al. 1994, Tucker \& Townshend 2000). As a result of persistent cloud cover, an inconsistent acquisition strategy and the absence of a regional Landsat ground receiv- 
ing station, the Central Africa region has an incomplete Landsat record. Pathfinder image interpretation from an area of approximately $411000 \mathrm{~km}^{2}$ where both Landsat TM imageries are available for the 1980s and 1990s reveals a deforestation rate of $0.43 \% \mathrm{yr}^{-1}$ with considerable variability for the different scenes across the Basin. The spatial variability appears to be primarily driven by population density and forest accessibility. Scenes with less forest area and good accessibility result in higher deforestation rates, even if the total deforested area within the scene is small.

\section{FOREST USE AND DEFORESTATION PROCESSES}

The tropical rain forests of Central Africa, although seen externally as pristine, are under various levels of exploitation. The Congo Basin is a mosaic of moist tropical upland and swamp forests, logging concessions, protected areas and subsistence agriculture (Fig. 1). The primary use of the forest is for timber extraction by selective logging. At a local level, communities extract non-timber forest products and protected areas provide a small and growing base for tourism.

\subsection{Logging status}

Logging impacts the greatest percentage of the forest area, relative to farming, mining and infrastructure development. However as most concessions are involved in highly selective old-growth forest mining (i.e., tree biomass accumulated over hundreds of years is being liquidated at a rate that far exceeds production rates), present impacts are primarily related to forest fragmentation and defaunation, and not land cover conversion. The size class distribution and regeneration capacity of economically valuable tree species, and plants and animals dependent on these tree species, are certainly adversely affected by selective logging, which often removes over $95 \%$ of all commercially valuable individuals $>60 \mathrm{~cm}$ diameter at breast height (dbh) (Wilkie et al. 1992). However, the highly selective nature of old-growth logging in the region typically damages less than $10 \%$ of the canopy (Wilkie et al. 1992). Although the canopy damage is relatively small, the impact of selected logging on carbon storage and sequestration rates is more significant, as trees $>60 \mathrm{~cm}$ dbh contain 20 to $35 \%$ of the total carbon biomass (Borry 1995). The impact of logging-based forest fragmentation on woody biomass, carbon storage, plant and animal species composition and abundance, and animal behavior is, however, highly varied, depending on the species being harvested, the logging techniques used, and the land and resource use postlogging (White 1992, White 1994, Struhsaker 1997).

\subsection{Non-timber forest products}

The majority of the region's 50+ million human inhabitants rely for some portion of their food, shelter and income on non-timber forest products (NTFPs) (Bahuchet \& de Maret 1995). NTFPs are a vital and effective insurance policy for economically marginalized families and are often harvested and sold to smooth consumption in expectation of, or subsequent to, economic shocks resulting from illness, deaths, crop losses, taxation and school fees (Godoy et al. 1998).

Any discussion of NTFPs is complicated by the range of products that originate from the forest (wood products: logs, sawn wood, poles, fuelwood, charcoal; nonwood products: bark, roots, tubers, corms, leaves, flowers, seeds, fruits, sap, resins, honey, fungi and animal products [which include everything from termites to elephants]); the factors that influence their availability over time; the enormous range of domestic and commercial uses for these products; and the complexity of the pathways along which forest products travel from producer to consumer. This is simplified only slightly by focusing on the potential climate change consequences of NTFP harvesting.

In ecological terms NTFP harvesting impacts primarily the distribution, abundance and age class distribution of individual species, thus it contributes to forest degradation not deforestation. Depending on the life history of the species involved and how the NTFP is harvested (whole plant, leaves, bark, fruits, resin, etc.), the impact of NTFP use on the population structure and long-term productivity of the resource may not be discernible in the short term (i.e., the impact of seed harvesting on tree regeneration may not be detected for 60 to $100 \mathrm{yr}$ for long-lived tree species). Not surprisingly, fast-growing, early-reproducing and abundant species are less susceptible to over-exploitation. However, local production to meet extra-local commercial demand most often results in the rapid depletion and local extinction of the targeted species (Wilkie \& Godoy 1996, Freese 1998). Unsustainable hunting of seed-dispersing animals (i.e., frugivores such as birds, antelope, pigs, elephants) will most likely alter the dispersal potential of tree species, affecting seed shadows, overall seed rain, and the probability of seedling survival. Ultimately this will alter the dominance hierarchies of up to $80 \%$ of the trees, and thus change forest structure and biomass (Tom Smith pers. comm.). How these changes in forest structure and species composition will affect rates of carbon sequestration and levels of carbon storage are unknown. 
In economic terms wild harvesting of NTFPs for the market is typically (based on evidence from other tropical forests) a short-term transitional economic option that provides an unsustainable revenue stream until logging benefits are made more equitable, until off-farm jobs become available, or until NTFP scarcity promotes domestic production. Domestication and cultivation of high commercial value NTFPs is, of course, likely to result in an increase in the rate of forest clearing, with associated declines in carbon stocks and carbon sequestration.

\subsection{Agriculture status}

Agriculture at present results in the most extreme form in land cover conversion and land use transformation but is limited in extent by low population density, poor roads, high transportation costs and a moribund global market for tropical agricultural commodities (Table 1). If we assume that all rural populations within the forest and all urban dwellers within major urban areas proximal to the forest eat only locally produced foods, then over 30 million people in the Congo Basin depend on the crops produced by household-level forest farmers to meet their daily food requirements. Based on the literature, we can conjecture that the average field area needed to generate $2000 \mathrm{Kcal}_{\text {capita }}{ }^{-1} \mathrm{~d}^{-1}$ for a year is approximately $0.1 \mathrm{ha}$, and that the average field is cultivated for 12 mo and then left fallow for 5 yr. Given this, then the total area of land needed for agriculture to feed the 30000000 forest-dependent central Africans is $180000 \mathrm{~km}^{2}$, or approximately $10 \%$ of the present tropical moist forested area of the Congo Basin. This would increase to $20 \%$ of the total area of each nation assuming that all food for all citizens was produced locally. Both estimates for land under agriculture or left fallow fall within the range reported by Laporte et al. (1998) from a land-cover analysis of $1 \mathrm{~km} \mathrm{AVHRR}$ satellite imagery covering the Congo Basin.

Given the available evidence (Table 2), even if the human population in the region were to double or
Table 1. Land cover percentages for Central Africa. Source: Laporte et al. (1998)

\begin{tabular}{|lcc|}
\hline & $\begin{array}{c}\text { Forest cover } \\
(\%)\end{array}$ & $\begin{array}{c}\text { Agriculture } \\
\text { and fallow (\%) }\end{array}$ \\
\hline Cameroon & 37 & 14 \\
Central African Republic & 10 & 10 \\
Democratic Republic of Congo & 48 & 4 \\
Equatorial Guinea & 65 & 23 \\
Gabon & 80 & 9 \\
Republic of Congo & 66 & 11 \\
Mean & 44 & 10 \\
\hline
\end{tabular}

triple and agricultural productivity were to remain constant (an unlikely assumption particularly in landscarce peri-urban areas), 80 to $90 \%$ of the area currently covered by forest would remain so. Even with a small area in agriculture at any one time, shifting cultivation will lead to an increase in the extent of secondary forests. The population-sparse nations of the Central African Republic, Gabon, and the Republic of Congo, are highly urbanized, are unlikely to experience an extensive increase in agriculture-driven deforestation over the next $25 \mathrm{yr}$, even with population growth rates that exceed $2 \% \mathrm{yr}^{-1}$, unless there is a dramatic increase in global prices for tropical crops. The remaining demographically dense nations (Cameroon, the DRC and Equatorial Guinea) may see the expansion of agriculture-driven forest clearing in peri-urban areas and alongside roads that have easy access to urban markets, but even this cannot be considered a severe threat to forest conservation in the short to midterm. Moreover, over the next $10-25$ yr the DRC may experience less extensive clearing for agriculture as its road network is more limited and less well maintained. The recent oil revenue windfall in Equatorial Guinea may promote a development path that mirrors that of Gabon, where agricultural production is minimal and food needs for the urban majority are met through importation.

Focusing on deforestation by household-level farmers in low population density regions of the Congo

Table 2. Statistics for Central African Countries (WRI 1998)

\begin{tabular}{|lcccrrr|}
\hline & $\begin{array}{c}\text { Area } \\
\left(\mathrm{km}^{2}\right)\end{array}$ & $\begin{array}{c}\text { Population } \\
(\text { millions })\end{array}$ & $\begin{array}{c}\text { Pop. density } \\
\left(\text { people } \mathrm{km}^{-2}\right)\end{array}$ & $\begin{array}{r}\text { GNP per capita } \\
(\$)\end{array}$ & $\begin{array}{c}\text { Roads } \\
(\mathrm{km})\end{array}$ & $\begin{array}{c}\text { Road density } \\
\left(\mathrm{km} \mathrm{km}^{-2}\right)\end{array}$ \\
\hline Cameroon & 475442 & 12.80 & 26.9 & 770 & 70570 & 0.15 \\
Central African Republic & 622984 & 3.20 & 5.1 & 390 & 23810 & 0.04 \\
Democratic Republic of Congo & 2344858 & 42.60 & 18.1 & 130 & 145000 & 0.06 \\
Equatorial Guinea & 28071 & 0.39 & 13.8 & 360 & 2820 & 0.10 \\
Gabon & 267667 & 1.30 & 4.8 & 4050 & 7633 & 0.03 \\
Republic of Congo & 342000 & 2.50 & 7.3 & 920 & 12760 & 0.04 \\
\hline
\end{tabular}


Basin as a way to reduce forest loss may not be the most strategic investment for 2 reasons: (1) farming in isolated, low population density regions of the basin is not a major factor in forest cover and forest quality change, and (2) farmers have little incentive to change their agricultural practices, particularly if they require increased labor or capital inputs, when labor is a major constraint, access to markets is limited (i.e., there is little economic incentive or capacity to adopt new practices) and there is abundant land for cultivation.

\subsection{Protected areas}

The Congo Basin forests comprise a unique and globally important storehouse of plants and animals. The region supports the largest unprotected populations of elephant in Africa, is home to 4 of the world's 5 species of great apes (Gorilla-mountain, eastern lowland and western lowland; Chimpanzee; Bonobo; and Human), and numerous other unique species such as Okapi, Bongo, and Congo Peacock. The forests contain at least 12000 species of plants and are home to over 400 species of mammals, 1000 species of birds, 300 species of reptiles and amphibians, 1000 species of freshwater fish, and almost 2000 species of butterflies. Approximately $6 \%$ of the terrestrial landscape $\left(230710 \mathrm{~km}^{2}\right)$ and almost $8 \%$ of the dense forest $\left(138191 \mathrm{~km}^{2}\right)$ has been set aside as protected areas, where biodiversity conservation is the primary land use (Fig. 1). Most of the forested protected areas support a relatively intact flora and fauna; are relatively isolated from roads, markets and sources of demand; and thus are likely to persist in the future. However, these areas, on average, receive barely $20 \%$ of the financing needed to ensure the long-term persistence of the habitats and species they were designed to protect (Culverwell 1998, Wilkie \& Carpenter 1999), and the human capacity to manage these reserves and parks is weak or non-existent.

\section{CARBON BUDGET OF THE CONGO BASIN}

Typically, there are 2 ways to estimate carbon emissions from deforestation for a region. The first one is by differencing carbon stocks between 2 periods. The second method is to directly calculate emissions from an estimation of the rate of deforestation and land-use change.

Estimated carbon emissions from Central Africa range from 0.02 to $0.41 \mathrm{Pg} \mathrm{yr}^{-1}$ for the time period 1980-1990 (Perlack et al. 1994, Gaston et al. 1998). Using land cover area estimates from FAO/UNEP
(1981) adjusted by FAO (1993) and a closed-forest biomass carbon density derived from forest inventories (Hall \& Uhlig 1991), carbon stocks in the central African terrestrial ecosystem in 1980 are estimated to be $28.92 \mathrm{Pg}$. This estimate might have a variation of $\pm 25 \%$, depending on the estimation parameters for the expansion factors used and errors in reporting areal extent (Hall \& Uhlig 1991). Using the average biomass density for non-forested areas in 1980 and the land cover area and total biomass of forests reported in FAO (1993), the total carbon stock in Central Africa for 1990 was $24.79 \mathrm{Pg}( \pm 25 \%)$. This estimate is similar to the estimate of $24.23 \mathrm{Pg}$ made by applying the carbon densities reported in FAO (1993) to the vegetation map from the TREES project (Mayaux et al. 1998). Differencing these 2 numbers gives a change in above-ground carbon stock in central Africa from 1980 to 1990 of -4.13 Pg, which would represent a $15 \%$ loss since 1980 . Clearly this number is subject to considerable error due to the uncertainty of the various inputs.

Given the uncertainty associated with using national survey data from 1980, estimating emissions from deforestation rates directly may prove more accurate. Taking preliminary results from the Landsat Pathfinder Project we calculate that, on average, deforestation occurred at a rate of $0.43 \% \mathrm{yr}^{-1}$, and carbon emission would be equivalent to $0.14 \mathrm{Pg} \mathrm{yr}^{-1}$. Although this number does not include carbon emissions associated with forest degradation, for example, through logging, it is clearly less than the emissions computed above. As the estimate of the rate of deforestation improves through increased availability of high-resolution satellite data, the uncertainty will be reduced.

While greenhouse gases are released through deforestation, these emissions are mitigated by the sequestration of carbon occurring as the result of forest regrowth as cultivated fields are abandoned and disturbed and logged areas recover. The ability to accurately estimate the extent and distribution of forest cover change in the region would allow for the development of a forest management strategy in the context of the climate change. Implementation of forestry initiatives such as selective logging, forest conservation, reforestation and other agroforestry options have the potential to greatly influence carbon fluxes in the region (Trexler et al. 1992, Cooper et al. 1996). At present the forests of the Congo Basin serve as a large reservoir of carbon, which is equivalent to approximately $5 \mathrm{yr}$ of total global emissions of $\mathrm{CO}_{2}$. Based on FAO reports (FAO/UNEP 1981, FAO 1993) above-ground carbon stocks in the Central African ecosystem dropped nearly 15\% between 1980 and 1990. 


\section{THE FUTURE OF THE FOREST: TOWARDS A PREDICTIVE MODEL}

\subsection{Underlying processes of land cover change}

An important question for those involved in forest management and biodiversity conservation planning or projecting future carbon emissions from the Congo Basin is how are the forests likely to change over the next few decades. As described above, 2 primary proximal factors are responsible for changes in land cover throughout the Congo Basin-agriculture and logging. Expansion of the former involves conversion of old growth or secondary forest into fields. Agriculturalbased deforestation tends to be geographically concentrated along roads, rivers or railways and extends centrifugally from human settlements. As and when the infrastructure is improved, agriculture will expand along these road networks. Logging more commonly results in forest fragmentation and biomass loss than in conversion of forests to other land cover types. Forest fragmentation from logging tends to be more extensive and typically occurs as a wave of disturbance that starts at the most accessible coastal forests and moves progressively into the more isolated hinterlands. The pace and intensity of both agricultural and logging-based forest cover change is largely a function of the farmgate price of crops and the free-on-board price of logs.

Simple models that incorporate decision-making rules can simulate the likely extent, geographic distribution, and impact of both farming and logging in the Congo Basin over time. Developing these exploratory models could provide decision makers and managers with useful 'what if' tools to estimate future carbon emissions, identify 'hot spot' areas of deforestation, assess future pressure on protected areas, and identify large contiguous blocks of forest for biodiversity conservation. The models would also have potential use in determining sites for carbon trading pilot studies and for the development of policy relevant to sustainable forestry and biodiversity preservation issues. The modeling approaches need to be flexible enough to incorporate new information as the data and our understanding of the processes are improved.

\subsection{Regional forest change prediction}

The approach adopted for this study was to develop a spatially explicit, rule based, probability model in a geographic information system (GIS) platform. The deforestation variables included in the simulation were: population growth from United Nations (1998), road density calculated from ESRI Digital Chart of the World, protected areas from the World Conservation
Monitoring Center (Sayer et al. 1992), the vegetation map from the TREES project (Mayaux et al. 1997), concession information from the World Resource Institute's Global Forest Watch (GFW) program, and national rates of deforestation from the FAO (1993). The modeling calculated deforestation probability at a resolution of approximately $10 \times 10 \mathrm{~km}$ based on deforestation variables described above for the time period of 1990-2050. The probability of each deforestation variable was scaled from 1 to 10 and determined subjectively based on recent deforestation occurrence as observed in the Pathfinder Landsat image interpretation for the time period of 1990-1995. The model included several assumptions: no new protected areas were established and no deforestation occurred within existing protected areas for the modeling period (i.e., 1990-2050). Since the scaling of the variables was calibrated using the deforestation pattern interpreted from recent Landsat images, the model assumed that the current deforestation processes would continue for the next 50 yr. This assumption is questionable; however the simulation is intended to serve as a baseline to demonstrate deforestation trends for the next $50 \mathrm{yr}$.

\subsubsection{Model results}

Two scenarios were modeled. In Scenario 1, the same area deforested annually for each country (as reported by FAO 1993) was deforested for each year for the period 1990-2050. Scenario 2 increased the rate of deforestation, initializing the model simulation with the same annual deforestation rate for each country (as reported per country FAO 1993). These rates were then linearly increased to the maximum value of $1.0 \%$ in 2050. Table 3 shows the modeled extent of forest in 2050 by country. Overall, Scenario 1 resulted in a $37 \%$ reduction in the forested area and Scenario 2 resulted in a $41 \%$ reduction in forested area for the same time period. The largest percentage change is seen for the DRC, i.e., $43 \%$.

Both model scenarios indicate a general shrinking of the contiguous primary forest inwards from the forest boundaries (Fig. 2). The most extensive changes can be expected in southern Congo, and coastal Cameroon and Gabon. Another active corridor of deforestation is along the Congo River where forest fragmentation is observed. The large area of forest located north of the Congo River within the DRC would be cleared and the roads for forest clearance would separate the forests in the DRC from those in other countries. Increasing penetration into the forest would also occur along the road network. For the Basin as a whole, currently contiguous forests would be fragmented into 3 large blocks, 1 of which is located in the triangular intersection of 


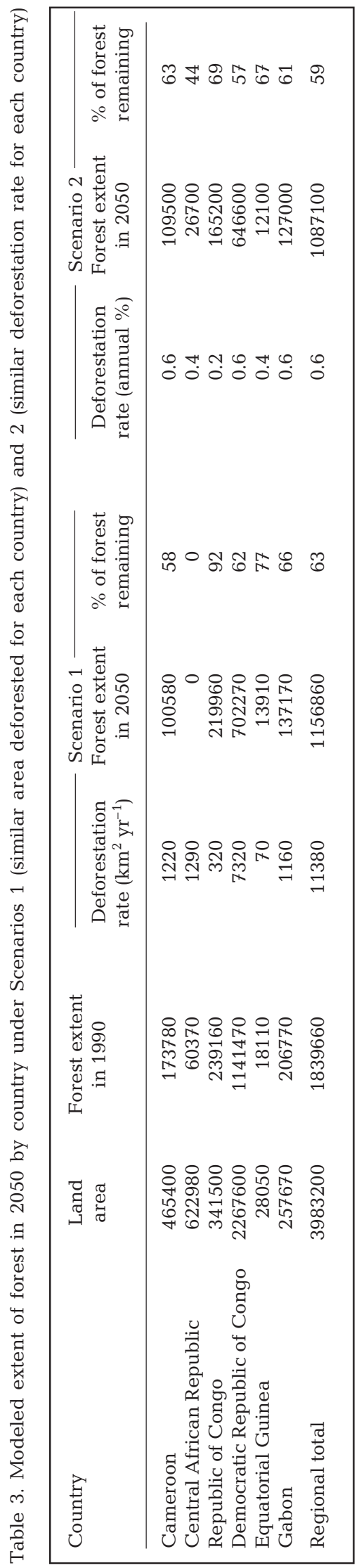

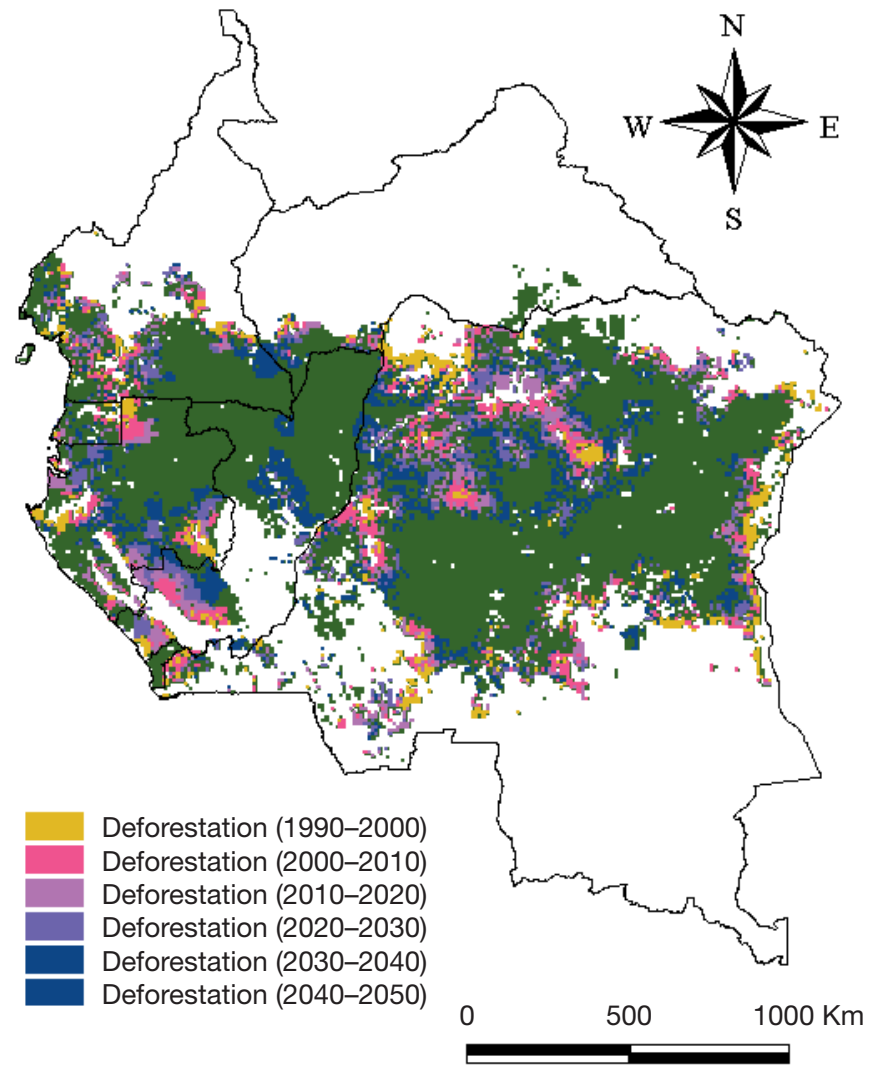

Fig. 2. Map of modeled forest extent from 1990-2050

Cameroon, Gabon and Congo, and the other 2 in the east and west of DRC. In addition to the regional fragmentation, a large number of small forest patches would remain as remnants along the periphery of forests. Using these projected area estimates to predict carbon emissions, we can estimate that over the next 60 yr emissions from the DRC would total 8.5 to $9.4 \mathrm{Pg}$.

The modeling used a number of deforestation factors to predict the future forest extent in the basin. To improve the reliability of the modeling prediction, several refinements would be needed. For instance, it is important to identify the active logging concessions in the Basin. Similarly it is necessary to understand how people utilize the forest resources in different regions. In addition, improvements to the spatial distribution of population and projected migrations within the Basin are needed. Undoubtedly, most of the driving factors of deforestation are related. It should be recognized that at the local level, these relationships vary by social, economic and cultural differences. Process studies to understand the causes of deforestation are needed to improve the predictive modeling. A long-term monitoring program capable of providing updated information on a 5 yr basis would improve the inputs to predict future changes. 


\section{CARBON AND BIODIVERSITY OPPORTUNITIES OF CARBON TRADING}

\subsection{Carbon trading}

Carbon dioxide is a potent greenhouse gas, and increased levels of carbon dioxide in the atmosphere have been linked to rising global temperatures with serious economic and environmental implications. Every year, carbon dioxide emissions from human activity pour just over 6 billion tonnes of carbon into the atmosphere. Approximately one-third of this amount is taken up annually by the world's forests. This discovery lies behind the proposal to limit the increase in greenhouse gas concentrations by planting more trees or reducing deforestation. It has been estimated that forestry could offset up to $15 \%$ of the world's greenhouse gas emissions (IPCC 1996).

The Kyoto Protocol, signed in December 1997, gave a major boost to the notion of forestry-based greenhouse gas mitigation by establishing the CDM. Under the CDM, industrialized countries could achieve cost-effective reductions in carbon dioxide emissions by investing in forestry carbon-offset projects in developing countries. Poor, forest-rich, tropical countries could therefore take advantage of their comparative advantage in providing an environmental service-rapid photosynthesis and carbon accumulation - to countries where carbon emissions would be relatively expensive (Richards \& Costa 1999). Carbon trading could be a new source of funding for tropical forest conservation (Totten 1999).

Attention has been focused on the possible use of the CDM to promote the broad-based adoption of reduced impact logging (RIL) in Central Africa. Tests from Brazil show that RIL not only reduces damage to the forest, but also increases the economic return per hectare of forest (Holmes et al. 1999). Combined with other policy measures, RIL could also reduce pressure on the region's remaining tracts of intact forest. RIL therefore has biodiversity and economic co-benefits that are consistent with the CDM's sustainable development goals (Austin \& Faeth 1999).

Increasing the region's contribution to mitigating atmospheric greenhouse gas emissions by reducing carbon sources and/or enhancing carbon sinks is of potential interest to carbon offset investors. Since these forests also hold some of the world's most unique wildlife, emissions reductions are relevant to both climate change and biodiversity conservation. But there is continued speculation over whether forestry will be included in the CDM, because of risks associated with the quantification, compliance, and permanence of the sequestered carbon.

The design of CDM-eligible projects in Central Africa faces some formidable technical and political challenges. Some of these are inherent in all forestry projects; others are specific to Central Africa, where the capacity to monitor conditions on the ground and to verify compliance is very weak. Three types of forestry projects can be envisioned in the framework of the CDM: forest conservation, reforestation and reduced impact logging.

\subsection{Potential carbon-related forestry projects}

\subsubsection{Forest conservation}

Forest conservation has been justified under the CDM on the basis of avoided deforestation. But many countries contest the eligibility of forest conservation under the CDM because of issues of additionality and leakage risks. Two additionality risks exist. First, a country could claim carbon offset credits simply by virtue of the size of its forest estate. Since the world's forests contain the equivalent of $20 \mathrm{yr}$ of greenhouse gas emissions, industrial countries could absolve themselves of the responsibility for implementing absolute reductions in fossil fuel emissions by buying credits from tropical countries. Second, avoided deforestation introduces a moral hazard, because countries may be encouraged to adopt policies that promote deforestation in order to demonstrate imminent threat to their remaining forest. Forest conservation in the face of logging is also prone to leakage. At the country scale, a significant improvement in enforcement would be required to ensure that effective protection in one area is not compensated by increased degradation elsewhere. But at the international scale, the growing demand for timber suggests that reduced exports from one country will be compensated by increased exports from others, leading to no net reduction in loggingbased carbon emissions.

\subsubsection{Reforestation}

Reforestation, which usually involves tree planting on degraded land, is less risky than forest conservation in terms of additionality, but may be more so in terms of permanence. There is a very high rate of plantation failures in the tropics, where Persson (1995) found that only $70 \%$ of the official plantation area actually existed on the ground. Although technical reasons were partly responsible, the main reason was that plantations were established without a clear market in mind. Cameroon, the only country in Central Africa where there has been significant investment in plantations, illustrates why reforestation projects are potentially risky, and hence not competitive, under the CDM. Cameroon's 
World Bank's 1982 forestry project was aimed at expanding the economic contribution of the forest sector by establishing 11000 ha of pine and eucalyptus plantations, and by strengthening the technical capacity of government agencies. An evaluation carried out in 1992 by the World Bank rated the outcome of the project as poor: very few trees were planted and many were destroyed by fire. The economic rate of return of many plantations turned out to be negative, a far cry from the standard minimum threshold of $10 \%$ required by the World Bank. The main problems were economic and institutional. The emphasis on industrial plantations under public sector control proved to be financially unsustainable and resulted in very poor performance in terms of seed stock production and cost recovery.

The failure of so many industrial plantations has led to a shift in emphasis to farmer and community-based projects. ICRAF's Alternatives to Slash and Burn (ASB) program, which assessed the impact of shifting cultivation on carbon emissions and biodiversity across various land cover types, has shown that small-scale agroforestry is both profitable and relatively rich in terms of both carbon and biodiversity. In Cameroon, the conversion of 1 ha of short fallow crop rotational land use to a cocoa agroforest could sequester up to 72 tonnes of carbon (Essama-Nssah \& Gockowski 1999). Cocoa agroforests are also effective at maintaining the biodiversity most valued by rural populations (Gockowski et al. 2000). Promoting cocoa agroforestry is not a new idea. What is different today, however, is the much improved economic environment for intensification. Producers are showing a renewed interest in their perennial crop systems following the removal of implicit producer taxation administered by the now defunct marketing board. The infusion of competition has also reduced marketing margins and increased producer incentives. But taking advantage of the new economic environment requires further liberalization and institutional reform to ensure the provision of services and inputs by the private sector, NGOs, and farmer organizations (Essama-Nssah \& Gockowski 1999). These changes are long term and are vulnerable to the region's endemic economic and political instability.

Industrial plantations and cocoa agroforests are thus prone to reversibility. One way to deal with this risk is to credit projects on the basis of ton-years, whereby permanence is calculated on the basis of ton-years of reduction in atmospheric carbon concentrations, discounted for the delay in sequestration relative to energy projects (Chomitz 1998). However, applying this method increases the cost of sequestering carbon in agroforestry projects almost 4 -fold for a 15 yr project, and almost 3 -fold for a 25 yr project, assuming a discount rate of $3 \%$ (Smith et al. 1999). If the much higher discount rates prevalent in Central Africa are used, reforestation projects become even less costeffective than energy projects.

\subsubsection{Reduced impact logging}

RIL has been proposed as a CDM-eligible project. Pioneering studies include the 5 yr New England Electric Systems pilot project in Malaysia (Totten 1999). RIL involves such practices as forest mapping, careful planning and building of roads and skid trails, climber cutting, directional felling, minimal use of bulldozers, and avoiding logging in the proximity of rivers and on steep slopes. Such practices can demonstrably reduce the amount of waste and damage to the cut trees and to the residual stand, thereby reducing carbon emissions. Because RIL leaves the forest in better condition, it also promotes higher carbon sequestration (Pinard \& Putz 1997). Implementing RIL in Central Africa is of special interest because of the boom in wood production in response to growing demand from Asia: log exports from the region rose from 2.4 million $\mathrm{m}^{3}$ in 1992 to 5.7 million $\mathrm{m}^{3}$ in 1997 (ITTO 1998). Production dropped in 1998 after the Asian financial crisis, but demand has since picked up, particularly from China following the introduction of a domestic logging ban in 1999.

RIL has never been formally tested in Central Africa, but experiments in Gabon and Cameroon suggest that RIL-type practices can double or triple the volume of wood harvested per hectare, and cause less damage to the surrounding forest (CIRAD 1998). Increased yields come from cutting off the buttress before felling (to reduce accidents and increase the portion of the trunk that is recovered), cutting off the branches (to allow the entire trunk and large branches to be extracted), and tracking trees with a simple marking mechanism (to prevent inventoried trees from not being cut and, much worse, cut trees from not being extracted). Taking into account the location of the marked trees when laying out the skid trails also reduces damage to the forest.

Simulating the impact of RIL on dipterocarp-rich forests in lowland Malaysia using detailed forest inventory data show that RIL can reduce logging damage from 40 to $15 \%$ at an additional cost of $\$ 150 \mathrm{ha}^{-1}$. This translates into carbon savings at a cost of \$3-5 ton ${ }^{-1}$ (Pinard \& Putz 1997). Up to $60 \mathrm{~m}^{3} \mathrm{ha}^{-1}$ is harvested in Malaysia. The cost per ton of carbon saved would be less in Central Africa, where the volume harvested rarely exceeds $15 \mathrm{~m}^{3} \mathrm{ha}^{-1}$, because of the more heterogeneous forests, the higher transportation costs, and lower processing value added. 
The cost of RIL is partly a function of the harvesting volume. Sustainable forest management plans, which usually incorporate elements of RIL, cost about $\$ 20 \mathrm{ha}^{-1}$ to design and implement in Central Africa (CIRAD 1998, Bakouma \& Buttoud 1999). If, based on results from Malaysia, we assume that for every $3 \mathrm{~m}^{-3}$ of wood cut, 1 tonne of carbon is released into the atmosphere, and that RIL can reduce this loss by two-thirds, then RIL in Central Africa would save 2 tonnes of carbon per hectare. This translates into carbon savings at a cost of $\$ 10$ tonne $^{-1}$, twice the figure from Malaysia, but still competitive relative to other forestry projects. Furthermore, this figure should be considered conservative as studies in other regions where harvesting intensity is also low (e.g., Brazil) have shown that RIL increases the profitability of logging (Holmes et al. 1999).

\subsection{Reduced impact logging and forest policy reform}

A broad-based adoption of RIL is consistent with the thrust of the World Bank-supported forest policy reforms, which are aimed at encouraging economic efficiency in the logging sector. In 1989, the World Bank commissioned a study of forest pricing and concession systems in Central Africa (Grut et al. 1991). The study, which provides recommendations governing the allocation, taxation, and management of forest concessions, forms the basis of the World Bank's forest policy reform agenda in Central Africa. Through policy reform, the World Bank believed that governments could prevent the worst logging damage and increase its share of revenue to help deal with its most pressing economic and social concerns.

The agenda is most advanced, and the impacts most evident, in Cameroon, where the World Bank has been engaged in forest policy negotiations with the government since 1989. The first phase of the negotiations, which culminated in the 1994 Forest Law, introduced 2 basic reforms (Brunner \& Ekoko 2000). First, concessions were to be allocated by auctions on the grounds that auctions are less susceptible to political pressure and more economically efficient than the previous discretionary practices. Second, the law introduced a significantly higher area tax indexed to inflation.

Theory suggests that these reforms will lead to higher volume harvesting from a smaller area and there is evidence from the introduction of the 1996 Forest Law in Bolivia that this is indeed the case. The Bolivian example yields several findings relevant to the eligibility and cost-effectiveness of RIL under the CDM. First, far-reaching changes in incentives and regulations appear to have had significant impacts on the geography and intensity of logging. Second, these changes are consistent with the sustainable manage- ment goals of forest certification. Since many of the principles and criteria of forest certification also feature in the package of practices that are considered to constitute RIL, there is a link between forest policy reform and the broad-based adoption of RIL-type practices. Third, intensification per se does not reduce emissions. In fact it would probably increase them, because more wood is extracted per hectare. But if intensification is balanced by conservation (i.e., there is increased land use specialization), the increased emissions may be counter-balanced by the prevented emissions from extensive logging.

The additionality of RIL thus depends on the difference between higher emissions (from intensification) and lower emissions (from conservation). Whether or not RIL results in a net reduction in carbon emissions has not yet been determined. But the fact that companies in Bolivia are building fewer roads (which are responsible for most of the logging damage) to extract the same volume of wood suggests that there has been a net reduction in logging-induced emissions. What we can conclude with more confidence is that emissions have fallen relative to the economic return from the sector. In other words, the sector's carbon efficiency has increased. There is also an ecological argument in favor of the higher intensity logging associated with RIL in Central Africa. Many of Central Africa's most valuable species require large clearings to regenerate. But the highly selective logging practiced in the region generates insufficient canopy openings to allow the regeneration of commercial species.

Establishing government credibility is an essential part of the reform process, and without a credible enforcement capacity, the incentive effects of auctions and area taxes are unlikely to be achieved. Indeed, perverse outcomes are possible. In Cameroon, higher area taxes, combined with inadequate law enforcement, a rapid expansion in wood processing capacity and a delay in concession allocation, have led to a wave of illegal logging as the cost of obeying the law has increased and the risk of being sanctioned has decreased. Bolivia and Cameroon show that the broadbased adoption of RIL requires both policy and institutional reforms.

Two specific research questions need to be answered before RIL can be broadly adopted in Central Africa: Is RIL profitable given the ecological and financial conditions in the region? If so, can changes in carbon be reliably monitored and credited? The demonstration that RIL may be profitable in Brazil has motivated a number of European logging companies to propose a similar test in Central Africa. CDM support could be used to co-finance such a test, ensure that the test meets the highest international standards and ensure that the results are made public. 
The next challenge is to test the net impact of RIL on carbon emissions. If RIL leads to higher yields per hectare, then within-concession emissions will increase. But if RIL leads to a reduction in the total logged area, then the net effect may be reduced emissions, because the remaining areas of forest would be unaffected by logging. Since poaching is strongly tied to the penetration of logging roads, a smaller area logged implies better wildlife conservation. To test the hypothesis that RIL leads to a net reduction in carbon emissions, tools are required to monitor changes in carbon over large areas of dense humid forest. One approach currently being explored is the use of space-borne ultra-longwave imaging radar systems designed to map changes in carbon. Implementing such systems remains a technical challenge that could justify CDM support.

RIL may be the most promising forestry carbon offset project type in Central Africa because, if implemented in conjunction with forest policy reforms and stronger government enforcement, it is less prone to the additionality, permanence and leakage risks than forest conservation or reforestation. Whether or not RIL is competitive relative to energy reduction projects remains to be seen. However, RIL could include significant economic and biodiversity co-benefits by virtue of its area-reducing and efficiency-enhancing effects. The broad-based adoption of RIL also implies improvements in government capacity that could have spillover effects in other sectors. A strong case can therefore be made to include RIL under the CDM.

\section{A VISION FOR THE FUTURE}

The authors' vision for the future is that for the Central African region there will need to be a tight coupling between effective forest management and any mitigation of climate change. There is a need to reconcile the differences between the national and local strategies based on the current economics of forest use and the largely externally driven agendas of carbon trading and biodiversity protection. To better position national policy makers, there is a need for improved scientific understanding of the options for forestry and carbon trading and an increase in support for climatechange-related research in the region.

\subsection{Forest management in the short term}

Though the rate of deforestation is low at present, forests in many areas of the Congo Basin are being fragmented and degraded. Loss of woody biomass and changes in species composition and abundance within fragmented forest are a concern from both global cli- mate change (GCC) and biodiversity conservation perspectives. Effective forest management is the key to slowing deforestation, reducing greenhouse gas emissions, increasing carbon sequestration and preserving biodiversity. The key factors driving forest fragmentation and degradation, and thus the key to short-term management of forests in the Congo Basin are logging and agriculture.

In regard to agriculture and contrary to apocryphal opinion, raising farm-gate prices and household income and providing secure land tenure increases rather than decreases deforestation by farmers (Godoy et al. 1997, Southgate 1998, Faris 1999). Thus integrated conservation and development projects that focus on raising incomes in rural communities around protected areas or managed forests are likely to increase not decrease the threat to forest conservation. However, unless non-agricultural uses of forests suddenly become more profitable, policy makers and development agencies interested in forest protection on the forest-frontier are left with the sole option of instituting more strident exclusionary policies-preventing the cutting of forests through legal measures and force. The problem of pursuing these policies is, of course, devoting scarce public resources to an activity that exacerbates poverty among rural households and possibly increases tensions. Alternatively, efforts focused on non-frontier areas designed to coax farmers away from the forest-frontier may constitute 'a winwin option for policymakers' (Faris 1999). Yet, longstanding theory and recent statistical evidence show clearly that neither urban growth nor manufacturing growth reduces poverty in low-income countries. It is the direct and indirect effects of agricultural growth that do so, and the indirect effects through expenditure of rising farm incomes are 2 to 3 times as important in poverty reduction as direct increases in employment in agriculture itself (Mellor \& Johnston 1998). Thus, in the long term, agricultural development targeted at non-frontier areas might both raise rural incomes and draw farmers away from the forest frontier, addressing poverty alleviation and forest conservation simultaneously.

Poor nations within the Congo Basin are looking to their forests as sources of revenue to fuel economic expansion. Timber extraction generates more cash per unit area for national treasuries, at present, than other land uses of the forest, such as agriculture, NTFPs and tourism (that is not to deny that agriculture and NTFPs presently may generate more revenue for local communities than does timber). Consequently logging is and will continue to be an important component of national economic development plans. Old-growth mining is advancing across the region and at current rates of exploitation there is probably less than 2 
decades of unlogged forest remaining in most nations (Gabon and the DRC may be the exceptions). During the mining phase access to forests is opened through the construction of logging roads and bushmeat flows out of the forest to urban markets. Forest fragmentation as a result of road construction increases the edge to surface area ratio of forest patches and may result in the substantial biomass collapse seen in the Amazon (Laurance et al. 1997).

Once the old growth mining phase of logging is over, the volume of timber that can be harvested from the forest per unit area will have to decrease (unless markets for new species appear) to sustainable levels (i.e., when harvesting equals production) if logging is to be a long-term component of local and national economies. However, assuming that wood production is the primary land use within concession forests, markets will largely determine the species that will be exploited and the size class that is harvested. Markets may also drive adoption of sylvicultural practices to enrich the forest with valuable species and thus effectively increase the homogenization of the landscape, the decline in species diversity and the fragmentation and degradation of 'natural' forests.

The challenge to understanding and tracking the impacts of logging over time will be to develop the tools and models needed to monitor forest fragmentation and forest patch degradation, particularly as the logging industry adapts to changing market conditions and the progressive decline in old growth forest. The challenge to managing the impacts of logging will be to balance the economic utility gained from logging with the loss of diversity likely within forests attributed primarily for timber production.

The logging industry in the Congo Basin is likely to follow the trajectory of forest use observed in all other regions in the world, in that (1) old-growth mining is a first step, (2) ecologically and economically sustainable natural forest management is a myth given present resource pricing systems, (3) plantation forestry or agriculture becomes established after old-growth mining ends, and (4) the logging industry evolves into a wood-processing industry in response to changing forest state and market forces.

Given the role that logging plays and will continue to play in the region, climate related forest management investments should focus on developing an integrated approach to (1) help promote development and implementation of policies and practices that maximize revenues from logging and keep ecological impacts to acceptable levels; (2) help build the capacity and institutions needed to effectively monitor and analyze forest state and forest use, and develop and enforce environmental standards and management regulations; (3) promote greater transparency, accountability and representation within forest management institutions; (4) push for greater equity in the distribution of benefits from, and costs of, logging; and (5) assist governments to develop appropriate policies to help the logging sector transition from old-growth mining to harvesting at production levels.

\subsection{Forest management over the longer term}

Lack of effective, representative, transparent and accountable institutions that regulate access to and disposition of forest resources is the single most important threat to long-term management of forests for the benefit of the majority within the Congo Basin. Selfgoverning institutions that regulate access to and disposition of wild resources do exist within small, stable, ethnically homogenous and economically autarkic communities. However, these institutions break down rapidly as communities grow and become more heterogeneous, as household economies become more integrated to markets, and as their influence conflicts with the interests of political and economic elites within the rentier economies typical of the region.

Most if not all central African states can be characterized as rentier economies because they generate almost all treasury revenues from the sale of mined natural resources (oil, diamonds, gold, timber, copper, etc.) to buyers outside the national economy (Moore 1999). As government revenue, sufficient to finance the running of government, to provide public goods and to pay for social services, is generated outside the national economy, rentier governments have almost no need to raise money nationally by taxing individuals or businesses. When governments have to raise money through national taxation they have a keen interest in the state of the national economy, because if the national economy is not healthy then tax receipts will be poor. Rentier economies have little interest in fostering development of a healthy national economy because they are not required to generate government revenues from the national economy.

So what does this mean to development options, forest conservation and climate change mitigation in Central Africa? The 4 take-home messages are (1) rentier governments are not directly dependent on national economic health because government spending is not predicated on receipts from national taxation $i(2)$ governments have little incentive to promote viable development projects as the national economy and the wealth of its citizens is immaterial to the capacity of the government to raise and spend money; (3) biodiversity conservation and climate change are therefore immaterial if they do not generate rent; (4) rentier states that merely allocate revenues generated external to the 
national economy will stifle a desire in citizens for effective representation in government and for government accountability.

Development of effective, representative, transparent and accountable forest management institutions that are supported by monitoring information and analyses generated by a cadre of well-trained technicians lies at the core of long-term management of the forests of the Congo Basin. Such governance institutions that result in decisions by, and benefits for, the majority are also key to meeting socio-economic development and biodiversity conservation objectives of local, national and international interest groups.

\subsection{Developing a climate-change research agenda for the basin}

The authors suggest that a climate-change research agenda for the Congo Basin might have a number of short-term goals, for example, to demonstrate the economic feasibility of carbon trading with the countries of Central Africa, to better quantify carbon stocks and fluxes and predict how they might change under different scenarios of forest management, to assess the likely impacts of climate change on national economies, human welfare and forest ecosystems of the region, and to strengthen or secure the necessary environmental monitoring and data management systems to provide underpinning for the research.

A short-term activity needs to be initiated to demonstrate and evaluate the feasibility of carbon trading in Central Africa. This activity might consist of exploratory studies to assess the economics, logistics and verification of different carbon trading options. Potential trading partners need to be brought together to participate in the design and pilot implementation and monitoring of these projects. Areas to be considered for initial pilots might explore RIL, agro-forestry and creation of new protected areas. This activity will need to be based on an established consensus between partners and a commitment from national governments.

Improved estimates of current carbon stocks and fluxes are needed to provide a more accurate input to the IPCC inventory. These improved estimates would include more accurate estimates of forest cover and type, location and rates of forest change including deforestation, regrowth, afforestation, selective logging and forest degradation. Improved access to affordable high-resolution remotely sensed data and low-cost image processing would enable national forest mapping agencies to provide up-to-date national forest maps with a goal of updating these maps on a $5 \mathrm{yr}$ basis. Access to new and appropriate remote sensing technology would facilitate the large-area mapping activities. This activity would ideally involve government institutes and universities in the region.

Biomass density measurements will be needed associated with the different forest types as well as improved estimates of biomass loss due to different logging practices. Examination of the quality of existing forest inventory data would be a good point of departure for this activity. Slight modification to current inventory methods to include non-timber species could provide a wealth of new data for carbon studies. Longterm forest monitoring plots could also provide useful information on rates of forest growth. The emerging Global Observation of Forest Cover (GOFC) project provides a useful forum and catalyst for promoting and developing operational use of remotely sensed and in situ data for forest monitoring (Justice et al. 1999; http://www.gofc.org/gofc/contact.html). A recent GOFC regional meeting in Libreville showed considerable interest from the Central African forest monitoring community in developing operational use of satellite data (Mayaux et al. 2000).

Although researchers have predicted various changes in climate at the global scale, the characteristics and impacts of climate change on Central Africa at a regional scale have yet to be determined. This research component needs to predict, with different confidence levels, future climate scenarios at the regional scale over the next $50 \mathrm{yr}$. Mesoscale climate models that downscale to the regional level are currently being developed, e.g., Semazzi \& Song (2001, in this Special). Such models need to be tailored to the geographic characteristics of the Congo Basin at a resolution that will, for example, need to resolve changes in the distribution, amount and timing of rainfall. Models with a cell resolution of between 10 and $100 \mathrm{~km}$ would appear to be appropriate. This high resolution is needed because when undertaking climate-change assessment, the model output would, for example, need to be coupled to ecosystem and hydrological models to understand the impacts on forest and river systems. Questions such as the impact on future river flow, fire frequency and distribution and agricultural production would need to be addressed (Stern \& Easterling 1999). To understand the economic and human health impact of climate change, it will be necessary to develop Integrated Assessment Models for the region (Desanker \& Justice 2001, in this Special). For tropical forest areas it will be important to integrate environmental changes that are driven by both climate change and the longterm land cover and land-use changes driven by population dynamics and regional development.

An important component of a climate change agenda will be to have the necessary underpinning data sets to identify trends and monitor changes in climate and initialize the predictive models. Meteorological networks 
are in decline worldwide and Central Africa is no exception. Resources are scarce at the national level for collecting environmental data; however, such information is critical for a planned development of the region in the context of a changing climate. As a first step assessment needs to be made of the weather and river monitoring systems of Central Africa and the status of the long-term records. A case needs to be made at the international level for sustaining long-term measurements, upgrading the equipment at existing stations and assessing if there are critical gaps in the monitoring network.

Each of the above topics has been discussed at a number of international workshops involving central African scientists over the last few years (e.g. Virji et al. 1998, Justice et al. 1999). Development of a global change research agenda developed by regional scientists, as exists for the Miombo Woodlands of Southern Africa, is a high priority for Central Africa (Desanker et al. 1997). The science networks for Central Africa clearly need to be strengthened and encouraged to develop their research priorities. Given the national priorities, such research will inevitably need some external support. The current international attention on climate change needs to translate into a strengthening of the capacity of regional scientists to participate in global change science research. The issue of scientific equity needs to be brought to the forefront. International global change programs such as the START program are ideally positioned to assist in developing and facilitating the implementation of such a research agenda (Fuchs et al. 1998). New initiatives such as the emerging National International Geosphere Biosphere Program (IGBP) Committee for the Democratic Republic of Congo are encouraging in this respect.

Acknowledgements. The authors acknowledge USAID-CARPE project for providing support for the research and analysis in the paper. The authors wish to than the Landsat Pathfinder Project for providing the data used in the deforestation analysis, ECE/JRC TREES project for providing the vegetation map, WRI Global Forest Watch for the concession map and Jim Graham (CARPE) and Jim Tucker (NASA/GSFC) for their encouragement for developing the climate change agenda in Central Africa.

\section{LITERATURE CITED}

Austin D, Faeth P (1999) How much sustainable development can we expect from the clean development mechanism? Climate Notes, World Resources Institute, Washington, DC

Bahuchet S (1990) A historical background of cultivated plants in Central Africa. In: Hladik CM, Bahuchet S, de Garine I (eds) Food and nutrition in the African rain forest. UNESCO-MAB, Paris, p 28-30

Bahuchet S, de Maret P (1995) State of indigenous popula- tions living in rainforest areas. European Commission, Brussels

Bakouma J, Buttoud G (1999) Sustainable forest management in Africa; constraints, costs, and conditions. International Tropical Timber Organization, Yokohama

Borry F (1995) Monitoring of tropical forest using spatial information techniques, Vol 1. Unit of Forest Management and Spatial Information Techniques, University of Gent

Braatz BV, Brown S, Ischei AO, Odada EO, Scholes RJ, Sokona Y, Drichi P, Gaston G, Delmas R, Holmes R, Amous S, Muyungi RS, De Jode A, Gibbs M (1995) African greenhouse gas emission inventories and mitigation options: forestry, land use-change and agriculture. Environ Monitor Assess 38:109-126

Brunner J, Ekoko F (2000) Cameroon. In: Seymour FJ, Dubash NK (eds) The right conditions. The World Bank, structural adjustments and forest policy reform. World Resources Institute, Washington, DC, p 59-80

Callendar B (1995) Scientific aspects of the Framework Convention on Climate Change and National Greenhouse gas inventories. Environ Monitor Assess 38:129-140

Chomitz K (1998) Baselines for greenhouse gas reductions: problems, precedents, and solutions, prepared for the carbon offset unity. The World Bank, Washington, DC

CIRAD (1998) Le projet d'aménagement pilote intégré de dimako, Cameroun, 1992-96. Série FORAFRI

Cooper PJM, Leakey RRB, Rao MR, Reynolds L (1996) Agroforestry and the mitigation of land degradation in the humid and sub-humid tropics of Africa. Expl Agric 32: 235-290

Culverwell J (1998) Long-term recurrent costs of protected area management in Cameroon: monitoring of protected areas, donor assistance and external financing, ecological and management priorities of current and potential protected area system. WWF Cameroon/MINEF, Yaounde

De Dianous S (1998) Gabon. Marchés Tropicaux et Méditerranéens

Desanker PV, Justice CO (2001) Africa and global climate change: critical issues and suggestions for further research and integrated assessment modeling. In: Desanker P (ed) Africa and global climate change. CR SPECIAL 8. Clim Res 17:93-103

Desanker PV, Frost PGH, Justice CO, Scholes RJ (1997) The Miombo Network: framework for a terrestrial transect study of land use and land cover change in the Miombo ecosystems of Central Africa. IGBP Report 41. IGBP, Stockholm

Essama-Nssah B, Gockowski JJ (1999) Forest sector development in a difficult political economy: an evaluation of Cameroon's Forest development and World Bank assistance, draft report. Operations Evaluation Department, The World Bank, Washington, DC

FAO (1993) Forest resources assessment 1990, tropical counties. FAO, Rome

FAO/UNEP (1981) Tropical forest resources assessment project, forest resources of tropical Africa, Part I: regional Africa. FAO, Rome

Faris R (1999) Deforestation and land use in the evolving frontier: an empirical assessment. Harvard Institute for International Development, Cambridge, MA

Freese CH (1998) Wild species as commodities: managing markets and ecosystems for sustainability. WWF/Island Press, Washington, DC

Fuchs R, Virji H, Fleming C (1998) Implementation Plan, 1997-2002. START Report No. 44

Gaston G, Brown S, Lorenzini M, Singh KD (1998) State and change in carbon pools in the forests of tropical Africa. 
Global Change Biol 4:97-114

Gockowski J, Nkamleu B, Wendt J (2000) Implications of resource use intensification for the environment and sustainable technology systems in the Central African rainforest. IITA, Yaounde

Godoy RA, Wilkie DS, Franks JR (1997) The effects of markets on neotropical deforestation: a comparative study of four Amerindian societies. Curr Anthropol 38:875-878

Godoy RA, Jacobson M, Wilkie DS (1998) Strategies of rainforest dwellers against misfortunes: the Tsimane' indians of Bolivia. Ethnology 37:55-69

Grut M, Gray JA, Egli N (1991) Forest pricing and concession policies: managing the high forests of west and Central Africa. World Bank Tech Pap 143, Africa Technical Department Series, The World Bank, Washington, DC

Hall CAS, Uhlig J (1991) Refining estimates of carbon released from tropical land-use change. Can J For Res 21: $118-131$

Holmes TP, Blate GM, Zweede JC, Pereira R Jr, Barreto P, Boltz F, Bauch R (1999) Financial costs and benefits of reduced-impact logging relative to conventional logging in the eastern Amazon, Final Report. Tropical Forest Foundation, Fundação Floresta Tropical, USDA Forest Service

Houghton RA (1995) Land-use change and the carbon cycle. Global Change Biol 1:275-287

Houghton RA, Boone RD, Melillo JM, Palm CA, Woodwell GM, Myers N, Moore B, Skole DL (1985) Net flux of $\mathrm{CO}_{2}$ from tropical forests in 1980. Nature 316:617-620

Houghton RA, Skole DL, Nobre CA, Hackler JL, Lawrence KT, Chomentowski WH (2000) Annual fluxes of carbon from deforestation and regrowth in the Brazilian Amazon. Nature 403:301-304

IPCC (1996) Climate change, 1995: impacts, adaptations and mitigation of climate change: scientific-technical analyses: contribution of WGII to the second assessment report of the Intergovernmental Panel on Climate Change. Cambridge University Press, New York

ITTO (1998) Annual review of the world tropical timber situation 1998. International Tropical Timber Organization, Yokohama. Available at: www.itto.or.jp/inside/review 1998/index.html

Justice CO, Horning N, Laporte N (1993) Remote sensing and GIS contributions to a climate change program for central Africa. In: Biodiversity Support Program (ed) Central Africa: global climate change and development. World Wildlife Fund, Washington, DC

Justice CO, Ahern F, Freise A (1999) Regional networks for implementation of the Global Observation of Forest Cover (GOFC) Project in the Tropics. START Report 4, START Secretariat, Washington, DC

Justice CO, Wilkie D, Putz J, Brunner J (in press) Climate change in sub-Saharan Africa: assumptions, realities and future investments. In: Sum Low P (ed) Climate change for Africa: science, technology, policy and capacity building, Kluwer Academic Publishers, Dordrecht

Kimes DS, Nelson RF, Skole D, Salas WA (1998) Accuracies in mapping secondary tropical forest age from sequential satellite imagery. Remote Sensing Environ 65:112-120

Kuik O, Gupta J (1996) Perspectives on Africa and the global debate on Joint Implementation. In: Maya RS, Gupta J (eds) Joint Implementation: carbon colonies or business opportunities? Southern Center for Energy and Environment, Harare, p 2-19

Laporte N, Justice CO, Kendall J (1995) Mapping the dense humid forest of Cameroon and Zaire using AVHRR satellite data. Int J Rem Sens 16:1127-1145
Laporte N, Goetz SJ, Heinicke M, Justice CO (1998) A new land cover map of central Africa derived from multiresolution, multitemporal satellite observations. Int J Reme Sens 18/19:3537-3550

Laurance WF, Laurance SG, Ferriera JM, Rankin-de Merona JM, Gascon C, Lovejoy TE (1997) Biomass collapse in Amazonian forest fragments. Science 278:1117-1118

Maley J (1996) The African rain forest-main characteristics of changes in vegetation and climate from the Upper Cretaceous to the Quaternary. Proc R Soc Edinb B Biol Sci 104:31-74

Maya RS, Churie A (1996) Critique of the African approach to negotiating JI-bargaining or posturing. In: Maya RS, Gupta J (eds) Joint implementation: carbon colonies or business opportunities (weighing the odds in an information vacuum). Southern Centre for Energy and Environment Climate Change Series 3, Harare, p 31-41

Mayaux P, Janodet E, Blair-Myers C, Legeay-Janvier P (1997) Vegetation map of central Africa at 1:5,000,000. Tropical ecosystem environment observation by satellites. Joint Research Centre, Ispra

Mayaux P, Achard F, Malingreau JP (1998) Global tropical forest area measurements derived from coarse resolution satellite imagery: a comparison with other approaches. Environ Conserv 25:37-52

Mayaux P, Justice CO, Sinse Lumbuenam R (2000) Observation par satellite des forêts d'Afrique Centrale: création du réseau GOFC - OSFAC, Libreville, 22-24 February 2000. EUR19585 Joint Research Centre, Ispra

McMaster DN (1962) Speculations on the coming of the banana to Uganda. J Trop Geogr 16:57-69

Mellor JW, Johnston BF (1998) The world food equation: interrelations among development, employment and food consumption. J Econ Lit 22:524-531

Moore M (1999) Death without taxes: democracy, state capacity, and aid dependence in the fourth World. In: White G, Robinson M (eds) Towards a democratic developmental state. Oxford University Press, Oxford

Nepstad DC, Verissimo A, Alencar A, Nobre C, Lima E, Lefebvre $\mathrm{P}$, Schlessinger $\mathrm{P}$, Potter C, Moutinho E, Cochrane MA, Brooks V (1999) Large-scale impoverishment of Amazonian forests by logging and fire. Nature 398:505-508

Ojwang JB, Karani P (1995) Joint implementation of GHG abatement commitments. In: Okoth-Ogendo HWO, Ojwang JB (eds) A climate for development: climate change policy options for Africa. Africa Centre for Technology Studies (ACTS), Nairobi, and Stockholm Environmental Institute (SEI), Stockholm, p 115-133

Okoth-Ogendo HWO, Ogallo L, Hulme M, Conway D, Kelly PM, Subak S, Downing TE (1985) Global climate change and the environment. In: Okoth-Ogendo HWO, Ojwang JB (eds) A climate for development: climate change policy options for Africa. Africa Centre for Technology Studies (ACTS), Nairobi, and Stockholm Environmental Institute (SEI), Stockholm, p 11-45

Oslisly R (1995) The middle Ogooué valley, Gabon: cultural changes and palaeoclimatic implications of the last four millenia. Azania 39-40:324-331

Oslisly R (2001) The history of human settlement in the middle Ogooué valley (Gabon): implications for the environment. In: Weber W, White LJT, Veder A, Naughtontreves L (eds) African rain forest ecology and conservation. Yale University Press, New Haven, p 101-118

Perlack RD, Graham RL, Prasad AMG (1994) Land-use management and carbon sequestering in sub-Saharan Africa. J Environ Syst 22:199-210 
Persson R (1995) Tropical plantation: success or failure? International Rural Development Currents, Uppsala

Pinard MA, Putz FE (1997) Monitoring carbon sequestration benefits associated with a reduced-impact logging project in Malaysia. Mitig Adapt Strat Global Change 2:203-215

Richards M, Costa PM (1999) Can tropical countries be made profitable by internalizing the externalities? Natural Resource Perspectives, No. 46, October 1999. ODI, London

Rodriguez Murillo JC (1997) Temporal variations in the carbon budget of forest ecosystems in Spain. Ecol Appl 7: 461-469

Sayer JA, Harcourt CS, Collins NM (1992) The conservation atlas of tropical forests: Africa. Macmillan, London

Semazzi FHM, Song Y (2001) A GCM study of climate change induced by deforestation in Africa. In: Desanker P (ed) Africa and global climate change. CR SPECIAL 8. Clim Res 17:169-182

Skole D, Tucker C (1993) Tropical deforestation and habitat fragmentation in the Amazon: satellite data from 1978 to 1988. Science 260:1905-1910

Skole DL, Chomentowski WH, Salas WA, Nobre AD (1994) Physical and human dimensions of deforestation in Amazonian. Bioscience 44:314-322

Smith J, Mulongoy K, Persson R, Sayer J (1999) Harnessing carbon markets for tropical forest conservation: toward a more realistic assessment. CIFOR Bogor

Southgate D (1998) Tropical forest conservation: an economic assessment of the alternatives in Latin America. Oxford University Press, Oxford

Stern PC, Easterling WE (1999) Making climate forecasts matter. National Academy Press, Washington, DC

Struhsaker TT (1997) Ecology of an African rain forest: logging in Kibale. University of Florida Press, Gainesville

Totten M (1999) Getting it right: emerging markets for storing carbon in forests, forest trends. World Resources Institute, Washington, DC

Townshend JRG, Justice CO, Skole D, Malingreau JP, Cihlar J, Teillet P, Sadowski F, Ruttenberg S (1994) The $1 \mathrm{~km}$ resolution global data set: needs of the International Geosphere Biosphere Programme. Int $J$ Rem Sens 15:3417-3441

Trexler MC, Haugen CA, Loewen LA (1992) Global warming mitigation through forestry options in the tropics. In: Sampson RN, Hair D (eds) Forests and global change,
Vol 1: opportunities for increasing forest cover. American Foresters, Washington, DC, p 73-96

Tucker CT, Townshend JRG (2000) Strategies for monitoring tropical deforestation using satellite data. Int J Rem Sens 21:1461-1471

UNESCO (1978) Tropical forest ecosystems: a state-of-knowledge report. UNESCO, Paris

United Nations (1998) World urbanization prospects, the 1996 revision. ST/ESA/SER.A/170, United Nations Publication, New York

USAID (1998) Climate Change Initiative 1998-2000. USAID Global Environmental Center, Washington, DC

Virji H, Fleming C, Aygepong G, Justice CO, Brunner J (1998) Land use and land cover change in west and central Africa: a workshop to develop a collaborative regional research effort. Accra, Ghana, 1997. START Report 1, Washington, DC

White LJT (2000) The African rain forest: climate and vegetation. In: Weber W, Veder A, Simons Morland H, White LJT, Hart T (eds) African rain forest ecology and conservation. Yale University Press, New Haven

White LJT, Oates JF (1996) New data on the history of the plateau forest of Okumu, southern Nigeria: an insight into how human disturbance has shaped the African rain forest. Global Ecol Biogeogr 8(5):355-361

White LJT, Oslisly R, Abernethy K, Maley J (1998) Aucoumea klaineana a Holocene success story now in decline? ORSTOM IRD, Paris

Wilkie DS (1994) Remote sensing imagery for resource inventories in central Africa: the importance of detailed field data. Human Ecol 22:379-403

Wilkie DS, Carpenter JF (1999) Can nature tourism help finance protected areas in the Congo Basin? Oryx 33: 332-338

Wilkie DS, Godoy RA (1996) Trade, indigenous rain forest economies and biological diversity: model predictions and directions for research. In: Ruiz Perez M, Arnold JEM (eds) Current issues in non-timber forest products research. CIFOR, Bogor, p 83-102

Wilkie DS, Sidle JG, Boundzanga GC (1992) Mechanized logging, market hunting, and a bank loan in Congo. Conserv Biol 6:1-11

WRI (1998) World resources 1998-1999. Oxford University Press, New York. Available at: www.wri.org/wr-98-99/pdf/ wr98_ei.pdf

Proofs received from author(s): June 25, 2001 